\title{
From Tsetse Control to Sustainable Rural Development - Progress and Opportunities for an Ethiopian Community
}

\author{
Johann Baumgärtner ${ }^{1,2}$ and Getachew Tikubet ${ }^{3}$ \\ 1 University of Milan, Milan \\ ${ }^{2}$ Centre for the Analysis of Sustainable Agricultural Systems (CASAS), \\ Kensington, $C A$ \\ ${ }^{3}$ Bioeconomy Foundation, Addis Abeba \\ ${ }^{1}$ Italy \\ ${ }^{2}$ USA \\ ${ }^{3}$ Ethiopia
}

\section{Introduction}

\subsection{Background}

Ethiopia is one of the poorest countries in the world in spite of long-standing efforts to improving the livelihood of the people and expanding their choices. The three essential but restricted choices for human development in Ethiopia and elsewhere are to lead a long and healthy life, to acquire knowledge, and to have access to the resources needed for a decent standard of living (OECD, 2011). To be sustainable, human development should satisfy the current needs without compromising the possibility of future generations to satisfy their needs (WCED, 1987). To encourage sustainable development, the United Nations member states and international organizations agreed to achieve the Millenium Development Goals (MDG) by the year 2015 (UN, 2005). For Ethiopia, Jobarteh et al. (2011) reported progress with respect to economic development and most MDGs with the exception of environmental sustainability. Namely, Jobarteh et al. (2011) put the country at extreme risk of food insecurity and vulnerable to climate change. Hence, it is unclear whether it can escape the vicious cycle of natural resource degradation and food insecurity driven by absolute poverty and population growth (Sisay Asefa \& Tesfaye Zegeye, 2003), also referred to as poverty trap (Eenhoorn \& Becx, 2009) or as 'poverty environmental degradation and food insecurity circle" (Shibru Tedla \& Kifle Lemma, 1998).

Poverty is the lack of, or the inability to achieve, a socially acceptable standard of living (Bellù \& Liberati, 2005). Basically, the inability refers to a situation in that individuals lack command over economic resources. In Ethiopia, extreme poverty defined by the World Bank as living on less than USD 1.25 per day is common (Ayalneh Bogale et al. 2002; Anonymous, 2011a). Environmental degradation becomes a result and a cause of economic stagnation and decline, which is aggravated by absolute poverty and food 
insecurity. Soil degradation is the severest environmental problem and Ethiopia loses about 400 tons/ha of topsoil every year (Shibru Tedla \& Kifle Lemma, 1998; Sisay Asefa \& Tesfaye Zegeye, 2003).

Food insecurity can be defined as the lack of capability to produce food and to provide access to all people at all times to enough food for an active and healthy life (World Bank, 1986). The average yield for food crops is low and has been growing only about 0.6 percent and lags behind the population growth of about 3 percent, resulting in an annual per capital decline of $2.4 \%$ in domestic food production (Sisay Asefa \& Tesfaye Zegeye, 2003). Livestock are extremely important to economic development and contribute to the livelihoods of $60-70 \%$ of the population (Haldermann, 2005). Animal husbandry is a local, multi-purpose activity, in that livestock produce food directly and provide key inputs to crop agriculture including fertilizers. Livestock not only provide poor people with food, income, traction and fertilizer but also act as catalysts that transform subsistence farming into income-generating enterprises, allowing poor households to join the market economy (ILRI, 2011). However, livestock health and multi-purpose productivity are severely constrained by inadequate feed and diseases transmitted by arthropods such as ticks and tsetse (Torr et al., 2002).

New technologies are important elements in Ethiopia's human development efforts (Aseffa Abreha et al., 2003). If selected, a single technology, however, should not be used as a silver bullet, i.e. a simple remedy for a difficult or intractable problem. In fact, silver bullets have been qualified as the most dangerous innovation misperception and an unpromising approach to development (Carpenter, 2009). Rather, technologies should be integrated into a system or package. Waage (2010) and Sayer and Campbell (2004) emphasized the important role that science plays in technology development and implementation. Rather than dealing with technology development, however, this paper focuses on the selection of technologies by rural communities, the integration of the selected technology systems into sustainable development efforts, and the evaluation of the impact. This requires taking into account the complexities of the ecological-social (ecosocial) systems, where the technologies are introduced, and a framework for impact assessment.

\subsection{Technology system selection and implementation}

A wide range of technologies should be considered. The restriction to low input technologies favoured by many specialists is inadequate because they suffer from poor adoption records (Tripp, 2006). The restriction to local and traditional technologies as the only legitimate, fair and appropriate technologies in a development context may be a constraint facing new developmental challenges including climate change and emerging diseases (Waage, 2010). Moreover, prejudices for technologies should be replaced with the understanding that being "appropriate" is not about where innovation comes from but about how useful it is (Waage, 2010). Chinsinga (2003) critizes technology transfer from the outside and little attention given to what motivates farmers to improve their land and husbandry systems. According to him, exogeneous forces to developing countries produce an unsustainable reform, the will has to spring from within developing countries with external stakeholders playing simply a facilitatory role. Samuel Gebreselassie (2006) shifts the attention from technologies to carefully designed 'innovation systems' where the promotion of new technologies is linked to processes of farmer innovation, social and 
cultural institutions governing uptake, and the economic and market conditions pertaining, particularly for poorer farmers in more marginal areas (Mitiku Haile et al, 2001; Ejigu \& Waters Bayer, 2005). These concepts were the driving force behind the establishment of onsite technology testing, demonstration and training units named BioVillages (Baumgärtner et al., 2001).

The implementation of technologies provides new opportunities that often raise ethical reflections on the basis of moral theories (Huppenbauer \& De Bernardi, 2003; Newton, 2003; Huppenbauer \& Bleisch, 2011).

Human development needs to take into account the complexities and multi-dimensionality of the problem (Sisay Asefa \& Tesfaye Zegeye, 2003). Briefly, a complex system is composed of many parts coupled in nonlinear fashion, has properties that cannot be fully explained by studying component parts, and the relationship between cause and effect is not as consistent as the regular, predictable simple systems we are familiar in dealing with (Gallagher \& Appenzeller, 1999; Holling, 2001; Jørgensen, 2009). Leong (2010) emphasises that we cannot proceed confidently on the basis of past knowledge to predict the consequences of our actions, nor the evolution of events around us. Moreover, we need to be prepared for surprises and select strategies based on creative thinking, experimenting with new ideas, observing their effects and increasing the probability of outcomes favourable to us (Leong, 2010; Resilience Alliance, 2010).

According to the traditional view, sustainability is composed of ecological, economic and social components. To deal with complexity and uncertainties in the outcome of development activities that expose the user to risk, adaptive management (AM) is recommended (Holling, 1978; Jiggins \& Röling, 2000). AM is a strategy that can readily be adapted during development to take into account of new knowledge during implementation (FAO, 2011). AM may allow to rely on an approach that is neither too reductionist to capture reality nor too comprehensive embracing "everything" instead of focusing on the stakeholders and processes that matter (Sayer \& Campbell, 2004). AM may also allow a balance between expensive external expertise and neglected local knowledge and may allow efficient use of models for understanding, actions and negotiations (Sayer \& Campbell, 2004). Finally, the widely used facilitation extension model can easily be integrated into an AM process (Röling, 1995; Gilioli \& Baumgärtner, 2007).

\subsection{Evaluation contexts}

To deal with complexity, Pawłowski (2008) proposes the integration of different spheres of human activity into a sustainable development program. Later-on, he defines a hierarchical system composed of level I with an ethical plane, level II with ecological, economic and social planes, and level III with a technology, a legal and a political plane (Pawłowski, 2011). According to him, the ethical plane is of fundamental importance because moral convictions determine human activities. Goodland (1995) proposed that ecological sustainability is the basis for social sustainability, and that it is achieved by keeping the scale of the human economic system within the biophysical limits of the ecosystem. Level III integrates technologies, legislation and politics as management instruments and part of governance that refers to the manner in which societies exercise power. Pawłowski (2011) emphasizes that the integration of levels and planes is needed but acknowledges that this is difficult to achieve. 
Adaptive governance becomes a form of social coordination with self-organizing and enforcing capabilities and relies on networks that connect individuals, agencies and institutions at multiple organizational levels (Folke et al., 2005). In Ethiopia and other African countries traditional governance structures (TGS) have survived the challenges of the forces of time. ECA (2007) asks for political commitment and courage to take bold decisions on the role and involvement of traditional authorities in the service delivering and good governance process.

The idea of sustainable community development confronts the typical community development practitioner in several somewhat distinct, though over-lapping contexts (Schmidt, 1997). Waltner-Toews et al. (2003) look at ecosocial systems from different perspectives. To evaluate the consequences of technology implementation for human development, reference is often made to the contexts of agroecological sustainability (Gliessman, 2000, 2007), ecosystem service provision (Daily \& Dasgupta, 2007) and ecosocial sustainability (Holling, 2001). Agroecological sustainability refers to the production by an ecosystem that maintains the resource base upon which it depends, relies on a minimum of artificial inputs from outside the farm system, manages pest and diseases through internal regulating mechanisms, and is able to recover from the disturbances caused by cultivation and harvest (Gliessman, 2007). Ecosystem services are not restricted to agroecological production but comprise ecological processes that sustain and fulfill human life. General distinctions exist between provisioning, cultural, and regulating ecosystem services (Koshel \& Mcallister, 2008). Ecosocial sustainability refers to a complex system in that humans are no longer external managers but become part of the system (Waltner-Toews et al, 2003). Ecosocial sustainability has ecological, economic and social dimensions in that respective ecological, economic and social capitals and their costs can be defined (Goodland, 1995). In this context, sustainable development is the realization of potentialities for enhancing the capitals with respect to costs (Costanza \& Daily, 1992; Gilioli \& Baumgärtner, 2007). Sustainability is also defined as the capacity to create, test, and maintain the adaptive capability or resilience of the ecosocial system, and sustainable development can be achieved by fostering adaptive capabilities (Holling, 2001).

Indicators are used to monitor changes in agroecological sustainability, ecosystem service provision and ecosocial sustainability. For example, the European Union recommends ecosocial sustainability assessment on the basis of complex set of indicators exemplified in Germany's report (ESDN, 2010). Often, the available information is summarized for sustainability assessments and recommendations (Anonymous 2011b).

\subsection{Scope of the chapter}

The paper summarizes the implications of technology selection and implementation for sustainable development in the Southwestern Ethiopian village of Luke. At project beginning, the income resulting from the sale of agricultural products and provision of labor to non-farming activities was less than one US \$ per day, indicating that the villagers were living in extreme poverty ( $c f$. UNSTATS, 2006). The productivity and well-being of the villagers were constrained by malaria to some extent, and increasingly, by food insecurity and limited opportunities for alternative income generation (Getachew Tikubet et al., 2006). Apparently, from ecological, economic and social standpoints, the Luke system operated at project beginning below the national average. 
To overcome these constraints, the Luke villagers took the initiative, sought assistance from international and national institutions, and prioritized activities.This analysis focuses on the first decade of technology implementation (1995-2005) and evaluates the progress in animal health improvement as a result of tsetse and disease control technology implementation. The consequences of the implementation of this and other technology systems are analyzed within Pawłowski's (2008, 2011) hierarchical system of sustainable development and evaluated in the contexts of $i$ ) animal health and ii) sustainable agriculture, iii) ecosystem service provision and $i v$ ) ecosocial sustainability. The evaluation from these different perspectives aims at the identification of opportunities for rendering the development more sustainable.

\section{Animal health improvement}

\subsection{Animal health constraints}

Many factors are responsible for the poor health and productivity of Ethiopian cattle. Several Trypanosoma spp. protozoans vectored mainly by tsetse Glossina spp. are responsible for the Nagana disease seriously affecting the health of livestock (Torr et al. 2002). In Africa, efforts to improve cattle health through vector control have a long history (Omamo \& d'Ieteren, 2003). In spite of decade old campaigns, both the disease and the tsetse vector are still very present on the continent. Omamo and d'Ieteren (2003) found literature information putting the number of cases of human trypanosomiasis in Africa at 300,000 and estimated the annual direct and indirect economic losses on the continent from animal trypanosomosis to be at least US $\$ 1.6$ billion and as high as US\$ 5 billion. For Ethiopia, Getachew Tikubet et al. (2003) provide specific information.

Torr et al. (2002) described the components of integrated Trypanosomiasis control. In summary, the application of trypanocidal drugs can keep cattle productive and is often the only affordable control technique. A study carried out in Southern Ethiopia, however, shows the costs are much higher because of cattle mortality and loss in draught power. Drug resistance is another factor limiting the usefulness of chemotherapy. The tsetse vector has frequent contacts with hosts, rapid movements, and viviparous and low reproduction that should be considered in control strategy design. The tsetse control operations are only promising if undertaken over a sufficiently large area. The two basic strategies are either eradication through insecticides or the introduction of a small but sustained level of mortality through baits including odor baited traps, insecticide treated target baits or natural baits such as cattle treated with pesticides. The Organization of African Unity (now African Union, AU) began a tsetse eradication initiative based on SIT (sterile insect technique) (OAU, 2001; Reinhardt, 2006). Dransfield et al. (1990), Leak et al. 1995), Saini et al. (1999) and Getachew Tikubet et al. (2003) provide examples for the efficiency of trap and cattle targets use in Kenya and Ethiopia.

\subsection{Methodology}

The Luke villagers sought help from Ethiopian national institutions and the Nairobi based International Centre of Insect Physiology and Ecology (ICIPE) to improve food security and livelihood. At the beginning of the activities, a project planning meeting took place under a big tree near Luke. Although the villagers lived in absolute poverty and suffered from 
multiple stresses including food shortage and diseases, they made clear that a project should give priority to animal health improvement and opted for a technology system composed of antitrypanosomal drugs and odour baited traps for tsetse monitoring and control. To make the control system efficient, they accepted project execution in an adaptive management framework, welcomed the assistance of ICIPE facilitators, participated in monitoring activities and made manpower available for control operations. The facilitators collaborated with ICIPE project managers and scientists from ICIPE and the Italian University of Molise (Baumgärtner et al., 2003).

Adaptive tsetse and trypanosomiasis management consisted of biweekly collection of data from monitoring traps and subjecting them to geostatistical analyses (Sciarretta et al, 2005a, 2005b, 2010). The resulting maps on tsetse distributions were passed to facilitators who presented them to communities for planning control operations. Adaptive management enabled them to respond to changes in actual tsetse distributions and to make efficient use of traps. They had knowledge on ICIPE's urine baited trap technology for disease vector control and opted for a disease control system based on traps and antitrypanosome drug administration by the Ministry of Agriculture. Odour baited traps were also used for monitoring purposes in other villages, but the technology of vector control with urine baited traps was acceptable to Mamede villagers and Luke farmers only. In the villages of Asosa and Keto, however, farmers preferred herd management to avoid tsetse infested areas and insecticide impregnated cloths (targets) to control tsetse, respectively (Baumgärtner et al., 2008c).

\subsection{Results}

The integrated pest management system composed of the trapping technology for tsetse monitoring and tsetse control, and drug administration to infected animals, was readily accepted by the Luke community and successfully implemented in collaboration with national and international partners (Getachew Tikubet et al., 2006). Geostatistical models were a useful tool for studying tsetse spatio-temporal distributions and guiding tsetse control operations (Sciarretta et al., 2005a, 2005b, 2010). From the organizational standpoint, the applied facilitation extension model was effective.

Figure 1 shows the decline in tsetse catches through time towards negligible numbers in 2006. In the same period, the disease prevalence decreased from 29 to about 10\% (Getachew Tikubet et al., 2006). Therefore, on the basis of disease prevalence reduction, the project can be qualified as successful. However, the information available is insufficient for a comprehensive cost-benefit analysis. Nevertheless, the financial support of about USD $20^{\prime} 000$ per year for a 10 years period provided by donors favourably compares to the estimated increase in income of about USD 300'000 per year for the entire Luke community (Baumgärtner et al., 2010).

\subsection{Discussion}

The decrease in trap catches and in the proportion of diseased animals is attributed to the application of the integrated pest and disease management system. The reduction of disease prevalence was substantial but remained at a low level. Presumably, trap catches do not represent tsetse densities and hence, are poorly correlated with disease transmission. 


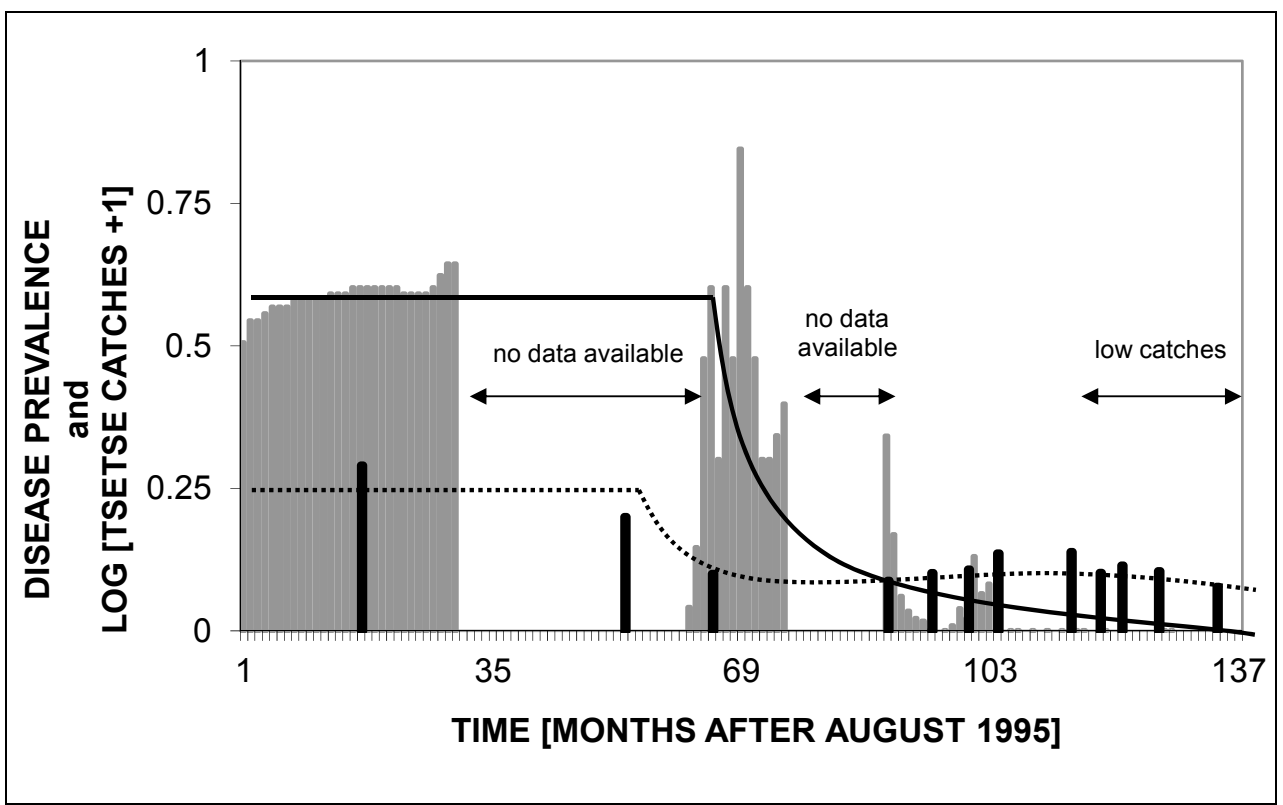

Fig. 1. The results of integrated tsetse and trypanosomiasis control at Luke, Southwestern Ethiopia, represented by the trends in biweekly tsetse trap catches $(\log$ (catches per day +1$)$, dashed line, light coloured bars) in odour baited traps and disease prevalence (proportion of infected cattle, dotted line, dark coloured bars).

Moreover, traps have been designed for the control of tsetse that is the biological vector of trypanosomes. However, Spickler et al. (2010) state that trypanosomes are also transmitted by mechanical vectors including biting flies such as horse flies (Tabanidae). The traps used at Luke may not be suitable for monitoring these vectors and hence, underestimate the vector potential.

The success in disease reduction through an apparently cost-efficient technology system is related to many aspects. The initiatives taken by the villagers through their traditional structures, the selection of the technology system, the motivation of the villagers, and their interest in implementing a facilitation extension model and taking advantage of the decision-support provided by external scientists were the key issues for meeting project objectives and confirm the utility of the concepts. The facilitators were experienced technicians able to efficiently communicate with villagers, national institutions and external scientists who provided models for knowledge acquisition, decision support and negotiations among stakeholders. In addition, most stakeholders recognized the advantages of models in the facilitation process (Baumgärtner et al., 2003, Schiarretta et al., 2005a, 2005b, 2010). The objective of animal health improvement was clear to all stakeholders who collaborated efficiently in spite of a diversity of views and difficulties in finding agreements on technology system implementation and method of interpretation.

Omamo and d'Ieteren (2003) identified inappropriate objectives, inadequate links between research and policy making, and insufficient social science input as major 
shortcomings of tsetse and trypanosomiasis campaigns. The objective aiming at animal health improvement defined in terms of disease prevalence was met. The strong links between scientists and facilitators on one hand and between facilitators and communal tsetse control committees on the other was a prerequisite for efficient project execution. The co-operation of facilitators and farmers with national institutions was not only indispensable for monitoring disease presence and for drug administration but also opened the door for the project to be considered in the Ethiopian national poverty alleviation agenda (Aseffa Abreha et al., 2003).

\section{Animal health improvement and human development}

\subsection{Introduction}

Rogers and Randolph (1988) and Barrett (1989) noted the possible negative consequences of tsetse control operations, and the current Pan African Tsetse and Trypanosomiasis Eradication campaign calls for thorough land use planning in tsetse control programs (OAU 2001; Reinhardt, 2006). Hence, the tsetse and disease control operations were accompanied by a program aiming at integrating animal health improvement into sustainable human development.

\subsection{Methodology}

To prevent the system from developing into an undesirable state, farmers were expected to implement additional technologies. Technology package selection and implementation by Luke villagers and their colleagues from neighboring areas were facilitated by an onsite technology testing, demonstration and training facility named BioVillage. The technologies for vegetable production and other activities included dipping irrigation, double digging, raised beds and organic fertilization, energy production in biogas digesters, and honey bee keeping (Aseffa Abreha et al., 2003; Herren et al, 2007). Facilitators working for ICIPE and the Yeha project of the Addis Ababa based BioEconomy Foundation (BEA) were expected to interact with the respective scientists and collaborators of Italian, German and US universities and to assist interested villagers in implementing the technologies of interest.

To improve the knowledge on the dynamics of the ecosocial system, to guide actions and to facilitate negotiations among stakeholders, a bioeconomic model was developed (Baumgärtner et al., 2008b; Gutierrez et al., 2009). In general, bioeconomic models are developed for better understanding pathways of development and for assessing the impact of alternative policies on the natural resource base and human welfare. They integrate important biophysical information and ecological processes with economic decision behavior (Regev et al., 1998; ICRISAT, 2009).

The consequences of technology implementation are evaluated within the contexts of agroecological sustainability (cf. Gliessman, 2000, 2007), ecosystem service provision ( $c f$. Hein et al., 2006) and ecosocial sustainabilty ( $c f$. Goodland 1995). A voluminous literature proposes indicators for assessing the sustainability in these three context. For example, Gliessman (2000, 2007), Meyerson et al. (2005) and UNSTATS (2008) provide important information on indicator selection and aggregation for respective assessments. In this case, however, the available financial and logistic means neither allowed the consideration of the literature nor the use of a 
comprehensive set of indicators. Instead, we made use of information readily available in national and regional statistics collected by Ethiopian Authorities and combined it with data published by Getachew Tikubet et al. (2006) and Baumgärtner et al. (2008b, 2010).

Agricultural sustainability is qualitatively assessed on the basis of sustainability concepts and parameters defined by Gliessman (2000, 2007). Hence, a conceptual model is used to tentatively assess inputs and qualify internal processes.

Ecosystem service provision is classified into production services, regulation services and cultural service, and assessed in biophysical terms (Hein et al., 2006). Undoubtedly, the information available is neither complete nor sufficiently reliable for undertaking a comprehensive evaluation of all services and go beyond a biophysical assessment towards a valuation of ecosystem services (Hein et al., 2006). In fact, the available data permit the quantification of milk, meat and tef (Eragostis tef) production at Luke, while the information on stocking rates and on the proportion of arable land to agricultural land allows a tentative qualification of some regulation services. Cultural services depend on the human interpretation of the ecosystem. Among the characteristics, there is nature and biodiversity, i.e. provision of habitat for wild plant and animal species, and provision of cultural, historical and religious heritage. In general, species biodiversity reaches a maximum at intermediate levels of management (Smith and Smith, 2000) and is quantified as follows. Hawando Tamirie's (2006) maximum stocking rate of $3.5 \mathrm{TLU}^{\mathrm{T}} \mathrm{a}^{-1}$ may represent intensive pasture exploitation, so that half of it (1.75 TLU ha-1) may be a plausible rate for intermedium pasture management. The estimated stocking rate - dependent biodiversity values are 0.51 (1995), 0.04 (2005) and 0.14 (2006) for pastures, while constant values of 0.01 and 0.20 are tentatively assigned to unmanaged land and arable land to take into account deforestation and low level of management intensity for tef, respectively. The biodiversity values obtained under different management intensities are multiplied by the surface of unmanaged land, tef and pastures. The sum is entered as a biodiversity index into Figure 2. Heritage provision may reach $0.1,0.8$ and 0.1 of the desirable levels in forests, arable lands and pastures. The multiplication by the respective surfaces and the summing up of the products yields an heritage provision index entered also in Figure 2. Additional information used to quantify ecosystem services is reported in Table 1. Figure 2 is a spider diagram, i.e. a graphical model often used for the assessments of ecosystem service provision (Hassan et al., 2005).

Ecosocial sustainability assessment is inspired by the summary of France's strategy that reconciles the ecological, economic and social aspects of human activities, undertaken on ecological, economic and social pillars of sustainability (Anonymous, 2011b). As previously stated, the Luke system initally operated below the national average at a low level of development. To faciliate the representation of changes, we make use of the initial assessment and report the changes relative to the national average or other suitable reference values. Specifically, the parameter values for Luke are related to the neighboring area (draught power requirements), to the poverty threshold (income) or to mean values for Ethiopia (population density, proportion of arable land; milk, meat and tef production, cattle number per person). Importantly, many variables are per capita (Table 2) and, hence, influenced by population growth. The variables and the source of the information is given in Table 2, while the information from Luke has been obtained from Getachew Tikubet et al. (2006) and Baumgärtner et al. (2008a, 2010). To show the changes, the calculated values are represented in a spider diagram (Figure 3 ). 


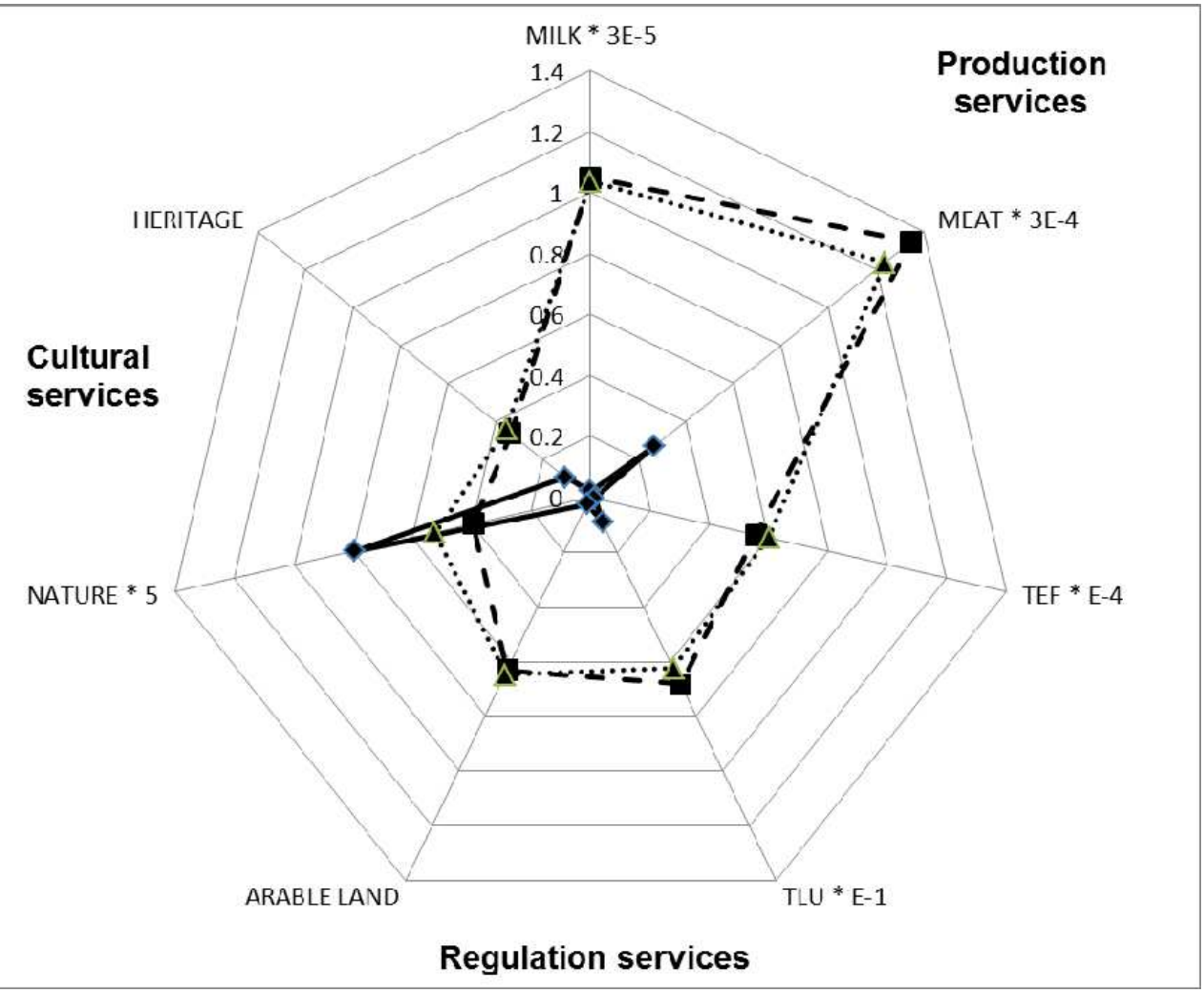

Fig. 2. Ecosystem service provision by the Luke ecosystemdivided into production, regulation and cultural services with readily available data $($ MILK $=$ milk production in 1 per year, $\mathrm{MEAT}=$ meat production in $\mathrm{kg}$ per year, $\mathrm{TEF}=$ tef production in $\mathrm{kg}$ per year, $\mathrm{TLU}=$ tropical livestock units, ARABLE LAND = proportion of arable land to agricultural land; NATURE = biodiversity index; HERITAGE = conjectured index of culture; diamonds and solid lines = data 1995; quadrats and dashed line = data 2005; triangles and dotted line = data 2006).

\subsection{Results}

Many farmers participated in training courses at the Biovillage technology testing, demonstration and training facility, but only few technologies including organic fertilizer production and to some extent, vegetable production, were adopted by the villagers. Interestingly, the villagers took the initiative to use the energy produced by the Biovillage biogas digester to pump water to the village. This can be interpreted as a positive response, although we expected the energy be used for cooking purposes to substitute dung cakes. 
From Tsetse Control to Sustainable

\begin{tabular}{|c|c|c|c|c|}
\hline $\begin{array}{l}\text { Ecosystem } \\
\text { service }\end{array}$ & Parameter & \multicolumn{2}{|c|}{$\begin{array}{l}\text { Information used for indicator } \\
\text { computations }\end{array}$} & Source of information \\
\hline \multirow[t]{3}{*}{ Production } & milk & $\begin{array}{l}\text { herd structure } \\
\text { lactation period }\end{array}$ & $\begin{array}{l}30 \% \text { cows } \\
279 \text { days }\end{array}$ & \multirow{2}{*}{$\begin{array}{l}\text { Tesfaye Mengistidie Dore } \\
(2007) \text {, Belete Anteneh } \\
\text { Tariku (2006), } \\
\text { Nell (2006) }\end{array}$} \\
\hline & meat & $\begin{array}{l}\text { average weight } \\
\text { off-take year-1 }\end{array}$ & $\begin{array}{l}268 \mathrm{~kg} \\
7.5 \%\end{array}$ & \\
\hline & tef (Eragrostis tef) & average yield & $1.1 \mathrm{t} \mathrm{ha}^{-1}$ & Heiniger (2009) \\
\hline \multirow[t]{2}{*}{ Regulation } & $\begin{array}{l}\text { erosion control, } \\
\text { soil fertility and } \\
\text { water holding } \\
\text { capacity }\end{array}$ & $\begin{array}{l}\text { Tropical livestock } \\
\text { units (TLU), } \\
\text { maximum }\end{array}$ & $3.5 \mathrm{ha}^{-1}$ & Hawando Tamirie (2006) \\
\hline & nutrient cycling & $\begin{array}{l}\text { proportion of } \\
\text { arable land to } \\
\text { agricultural land }\end{array}$ & & $\begin{array}{l}\text { Getachew Tikubet al. (2006), } \\
\text { Baumgärtner et al. (2008b, } \\
2010)\end{array}$ \\
\hline \multirow[t]{2}{*}{$\begin{array}{l}\text { Cultural } \\
\text { service }\end{array}$} & $\begin{array}{l}\text { biodiversity and } \\
\text { nature }\end{array}$ & $\begin{array}{l}\text { relation to } \\
\text { intermediate } \\
\text { management }^{\mathrm{a}} \\
\end{array}$ & \multirow{2}{*}{$\begin{array}{l}\text { proportions for } \\
\text { forests, arable } \\
\text { land, and } \\
\text { pastures (see } \\
\text { text) }\end{array}$} & \multirow[t]{2}{*}{$\begin{array}{l}\text { Estimates and conjectures } \\
\text { by the authors }\end{array}$} \\
\hline & heritage & $\begin{array}{l}\text { perceptions by the } \\
\text { community }\end{array}$ & & \\
\hline
\end{tabular}

Table 1. Ecosystem services provided by the Luke ecosystem in Southwestern Ethiopia: information used for constructing the spider diagram (Figure 1) (max. = maximum, $\mathrm{a}=$ for the concept, see Montagna et al., 2011).

\begin{tabular}{|c|c|c|c|}
\hline $\begin{array}{l}\text { Dimension } \\
\text { (plane) }\end{array}$ & Parameter & $\begin{array}{l}\text { Reference } \\
\text { quantity }\end{array}$ & Information source \\
\hline \multirow[t]{2}{*}{ Ecology } & $\begin{array}{l}\text { Tropical livestock units } \\
\text { (TLU) } \text { ha-1 }^{-1} \text { maximum }\end{array}$ & 3.5 & Hawando Tamirie (2006) \\
\hline & Population densitya ha-1 & 75 & $\begin{array}{l}\text { TradingEconomics (2011) } \\
\text { [http://www.wikipedia.org/] }\end{array}$ \\
\hline \multirow[t]{4}{*}{ Economics } & $\begin{array}{l}\text { Per capita income (poverty } \\
\text { line) per day }\end{array}$ & 1.25 USD & Anonymous (2011a) \\
\hline & \begin{tabular}{|l|}
$\begin{array}{l}\text { Draught power (number of } \\
\text { oxen per ha-1 }\end{array}$ \\
\end{tabular} & 1.9 & Gryssels et al. (1984) \\
\hline & $\begin{array}{l}\text { Per capita milk consumption }{ }^{a} \\
\text { year- }^{-1}\end{array}$ & 191 & \multirow[t]{2}{*}{ Belete Anteneh Tariku (2006) } \\
\hline & $\begin{array}{l}\text { Per capita meat } \\
\text { consumption }^{\text {a }} \text { year }^{-1}\end{array}$ & $13.9 \mathrm{~kg}$ & \\
\hline \multirow[t]{3}{*}{ Sociology } & $\begin{array}{l}\text { Tef (Eragrostis tef), yield ha-1 } \\
\text { Area under cultivationa }\end{array}$ & $\begin{array}{l}1.1 \mathrm{t} \\
2457000 \mathrm{ha}\end{array}$ & Heiniger (2009) \\
\hline & Livestock number ${ }^{a}$ & 143.33 mio & $\begin{array}{l}\text { Netherlands - African Business Council } \\
\text { [http://www.nabc.nl/] }\end{array}$ \\
\hline & School attendance & 1.0 & Target defined by stakeholders \\
\hline
\end{tabular}

Table 2. Reference parameters and the source of the data for the evaluation of ecological, economic and social sustainability in relation to reference parameters in the Luke community, Southwestern Ethiopia, reported by Getachew Tikubet et al. (2006) and Baumgärtner et al. (2008b, 2010) ( ${ }^{a}=$ area and numbers reported for Ethiopia). 


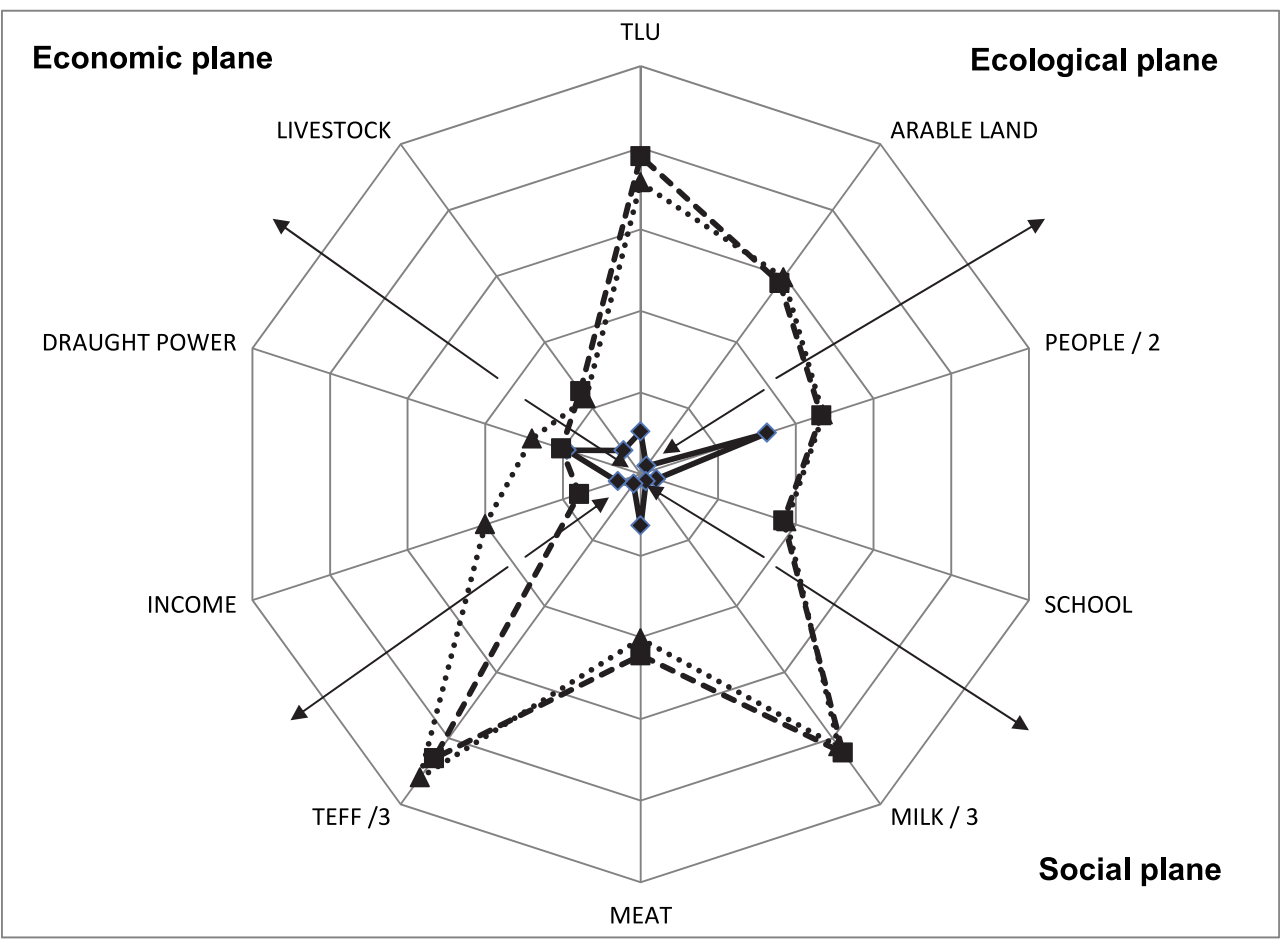

Fig. 3. The ecosocial sustainability of the Luke community, depicted on ecological, economic and social planes in that readily available variables are represented relative to reference values $(\mathrm{TLU}=$ tropical livestock units, $\mathrm{ARABLE} \mathrm{LAND}=$ proportion of arable land to agricultural land, PEOPLE $=$ population density, $\mathrm{SCHOOL}=$ proportion of Luke children attending the school, MILK / $3=$ milk production, MEAT $=$ meat production, TEF $/ 3=$ tef production), INCOME = income relative to one US \$ per day, DRAUGHT POWER = need of oxen relative to number of 1.9 in a neighboring area, LIVESTOCK $=$ number of cattle per person) (diamonds and solid lines = data 1995; quadrats and dashed line $=$ data 2005; triangles and dotted line $=$ data 2006; the scales for the axes are 0.5 , the arrows point to the deviations from the reference values).

The bioeconomic model proved to be valuable tool for a comparative analysis of transformability of ecosocial systems and for obtaining insight into the dynamics of the ecosocial system after technology implementation (Baumgärtner et al., 2008b). A high degree of transformability was thought to facilitate adaptive governance. Nevertheless, the stakeholders made little use of the model in the facilitation process. Information exchange among stakeholders was less frequent than in the animal health project component and project execution suffered from diverging views on methodologies and objectives among stakeholders. Hence, in the 1995-2006 project period, the facility extension model applied to human development or enhancing sustainability was not effective. Figures 2 and 3 show that, irrespecitive of the context, substantial changes occurred from 1995 to 2005, but only small differences were recorded between 2005 and 2006. 
From an agroecological standpoint (cf. Gliessman, 2000, 2007), livestock health has been improved through the input of an external tsetse trapping and therapeutic disease control technologies rather than through a hypothesized activation of internal regulating processes Disease prevalence has decreased but the number of diseased animals has increased (Getachew Tikubet et al., 2006). Consequently, a farmer keeps more livestock but has to invest more into drugs that amount to one US \$ for treating one animal. The increasing amount of antitrypanosomal drugs further augment the external input into the system. Importantly, as a result of animal health improvement, draught power became available (Yigzaw Dessalegn \& Yohannese Mehari, 2007). However, the 2.7 ha ploughed by one ox in 2005 is far above the 1.9 ha average reported by Gryssels et al. (1984) in a neighboring area. Hence, the oxen may suffer from work stress unless additional oxen are imported which would again increase the inputs. The substantial increase in arable land occurred the costs of a reduced pasture area. This reduction and the concomittant increase in cattle resulted in overgrazing that may have exposed livestock at a nutritional stress even if crop residues are used as feed. Since dung is preferentially used as a source of energy for cooking and for fertilizing house gardens, only a small amount of nutrients may find the way as fertilizers to arable crops. Increased reliance on external inputs, stressed draught power and inefficient distribution of fertilizer indicate that technology implementation resulted in a decreasing agroecological sustainability.

From the standpoint of ecosystem service provision (cf. Hein et al., 2004), the Luke community benefitted from measurable increases in milk, meat and tef production but suffered from a decrease in regulation services (Figure 2). In fact, overstocking may negatively affect soil fertility, erosion and water holding capacity, while the ratio of arable land to agricultural land indicates constrained nutrient cycling. In fact, the ratio of 0.6 is much higher than ratio of 0.4 reported for Ethiopia in 2008 indicating that too much land is being ploughed. The reduction in cultural services through a decrease in biodiversity and nature is mainly due to either relatively low (arable land) or high levels of management (forests, pastures). However, cultural services appear to be somewhat improved through better heritage conservation achieved through the traditional integration of arable land into the farming systems. As opposed to production and regulation services with a measurable background, however, the proportions representing the level of cultural ecosystem service provision are merely useful conjectures for tentatively showing the change.

From the ecosocial standpoint (cf. Goodland, 1995; Holling, 2001), significant changes occured in selected variables on ecological, economic and social planes with respect to reference values (Figure 3). For following the change, the innermost lines connecting the values obtained in 1995 should be compared with the outer lines conecting the 2005 and 2006 values. The deviations from 1 indicated by the arrows represent the differences from the reference values. On the ecological plane, the Tropical Livestock units (LTU), the proportion of arable and the population density were below the reference value in 1995 and far above in 2005 and 2006. This is seen as an indication that the carrying capacity of the Luke system has been exceeded and that the ecological basis cannot sustain the development on economical and social planes any more. On the economic plane, both the livestock asset and the draught power have substantially increased albeit without reaching the reference value, while the income has reached the poverty line (Anonymous, 2011a). Apparently, the resources available for livestock became insuffient for cattle and oxen numbers to reach the reference values. Nevertheless, given the interest in poverty alleviation 
and the importance of livestock as an asset to hedge against disasters (Haldermann, 2005), the progess on the economic plane is remarkable. On the social plane, Figure 3 also shows significant progress. Namely, school attendance is close to the the target of $100 \%$, meat production has reached the reference value, while tef and milk production have far exceeded it. Presumably, the nutrition has greatly improved and the surplus has increased the income. In summary, there is a risk that the progress on economic and social planes is no longer sustained by the ecological basis. This is interpreted as unbalanced and hence, unsustainable development.

\subsection{Discussion}

During the decade under study, few attempts were made to correct the level of unsustainability of the agroecological system, to improve ecosystem service provision and to balance the development in ecological, economic and social dimensions. Specifically, technology adoption was limited, models were hardly used in the facilitation process and the ratio of project costs to benefits seems to be unfavourable. Several factors may contribute to these shortcomings.

Probably, there was simply no sufficient time for villagers to recognize the problems and to react to apparently deteriorating agroecological and ecological conditions. Morover, the facilitation extension model was not effective primarily because there was limited interaction between stakeholders. Because of limited logistic and financial support as well as a lack of interest by many stakeholders, the on-site demonstration and training facilty was poorly managed. Apparently, the diverging views of and the operating on different moral systems by stakeholders was a major obstacle to project execution (Baumgärtner et al., 2008a).

The models developed by Baumgärtner et al. (2008b), Gilioli and Baumgärtner (2007), Herren et al. (2008) and Gutierrez et al., 2010) were hardly considered by the stakeholder community. Among the reasons was the late availability of the models, unclear objectives, few financial resources, and diverging views on methodologies. Moreover, the stakeholder community was unaware of the need to engage the participants into a modelling process and to develop and use a variety of models for different purposes (Peterson et al. (1997). The lack of interest is surprising since the bioeconomic model proved useful for the assessment of system transformability and for predicting the trajectory of the ecosocial system towards a collapse unless the villagers engage in reproductive health programs and take into account the limitations of the natural resource base (Baumgärtner et al., 2008b; Gutierrez et al., 2009). Conceptual models on ecosystem service provision and sustainability models proved to be useful for comparing the Luke agropastoral system with an Alpine system which both depend on managing common-pool natural resources. To avoid overgrazing, the Luke community was advised, among others, to integrate stocking rules into governance (Baumgärtner et al., 2010).

The provision of ecosystem services depends largely on the intensity of pasture management. Importantly, the Luke pasures are common pool resources that generally face the problem of overuse. Namely, according to the "Tragedy of the Commons" (Hardin, 1968), a herdsman will try to keep as many cattle as possible on the commons because he receives all the proceeds from the sale of the additional animal (positive utility) but shares the effects of overgrazing with all other herdsmen (negative utility). However, the "Tragedy 
of the Commons" is possible but not inevitable (Ostrom et al., 1999) and in Luke, could be avoided by improving adaptive governance (Baumgärtner et al., 2010).

Pawloski's ( 2011) hierarchically organized planes, the evaluations carried out in different contexts (Goodland, 1995) and the here proposed conceptual and graphical models provide important insight into the changes and can complement the bioeconomic model as evaluation tools in the facilitation process. There is room for further improving impact assessment: the current analysis is restricted to agricultural and unmanaged land and disregards home gardens which are an important contributor of food. False Banana (Enset, Ensete ventricosum) is a traditional staple crop in Luke and of particular interest in securing food supply under difficult conditions for agricultural production. Moreover, a difference should be made between unmanaged land and partially deforested areas.

\section{Opportunities for sustainability enhancement}

According to many Ethiopian researchers, human development requires poverty reduction and the overcoming of both environmental degradation and food insecurity (Shibru Tedla \& Kifle Lemma, 1998; Sisay Asefa and Tesfaye Zegeye, 2003). Presumably, the Luke villagers were aiming at similar objectives when they sought external help and initiated their efforts with improving animal health. For them, livestock is an asset used as hedges against risk and disaster (Haldermann, 2005). Most of the stakeholders, however, accepted the prioritization of animal health with reservation and emphasized instead the need to enhance sustainability in human development efforts. Apparently, unclear objectives were less of a hindrance in animal health improvement efforts than in selecting and implementing technology packages for sustainable development. In this case, project execution was plagued by disagreements on methodologies and conflicting views on objectives. The use of Pawłowski's (2011) hierarchical system may be useful for structuring discussions and provide a comprehensive framework for negotiation and reconciling stakeholder disagreements. The evaluation of sustainable development from the perspective of agroecological sustainability ( $c f$. Gliessman, 2007), ecosystem service provision ( $c f$. Daily \& Dasgupta, 2007) and ecosocial sustainability ( $c f$. Goodland, 1995) may better respect diverging views among stakeholders and contribute to reaching goals in a more efficient manner. Coordinated efforts towards common objectives, without insisting on agreed definitions (Owen, 2003), would pave the road to better cooperation among stakeholders than done so far.

Ethicists differentiate between consequential (e.g. utilitarian), deontological (duty-based) and virtue based moral systems (Huppenbauer \& Bernardi, 2003; Newton, 2003; Huppenbauer \& Bleisch, 2011). The members of the stakeholder community appear to operate on the basis of diverging moral systems (Baumgärtner et al., 2008a). According to the ecological pragmatism of B. G. Norton (Georgia Institute of Technology, Atlanta, USA) several divergent moral theories, which do not even agree on the determination of environmental ethics issues, can nevertheless work together as part of a single moral enterprise even though their respective commitment is in practice based on very different theoretical considerations (Afeissa, 2008). However, the fundamental role of ethics in Pawłowski's (2011) system of sustainable development and our experiences indicate that particular efforts are needed to setting up dialogues and to respecting pluralistic views for strengthening the cooperation in working towards common objectives. 
The slow adoption of Adaptive Management (AM) and the reluctance in integrating a modelling process useful in knowledge acquisition, decision support and negotiation was a major hindrance for project execution. Towards the end of the project period, however, most stakeholders recognized the utility of AM and the important role of models in connecting research with management so that the research meets management needs and management helps answer relevant research questions (Sayer and Campbell (2004). A more intensive dialogue among stakeholders than done so far is considered indispensable for making efficient use of mathematical, conceptual and the here presented graphical models.

Apparently, technology testing, demonstration and training at the Biovillage site were difficult to build into the facilitation process and had only a limited impact. However, Sayer and Campbell (2004) recognize that uncertainties and complexities require continuous learning through trial and error, analyzing mistakes and successes should be equally rewarding. The facilitation process employed in this project emphasizes the learning process and, albeit not recognized by all stakeholders, did allow for trial and error. Moreover, the demonstration and training site does not necessarily restrict technologies to preconceived notions of stakeholders (Tripp, 2006) and allows improvements of already implemented technologies (Newton, 2003). In the evaluation of the project, the criteria of technology selection and implementation may be overemphasized. Sayer and Campbell (2004) argue that indicators of natural resource system performance should reflect adaptability and a capacity for learning, rather than, for example, increased yields or adoption of new technology. An evaluation of the succeeding phase (2007-2011) may allow a revision of the methodologies and a re-interpretation of the results.

During the project phase (1995-2006) the fundamental role of adaptive governance was increasingly recognized by some but not all stakeholders. Accordingly, societies can improve adaptive governance through the continuous improvement of structures and processes by which they share power to shape individual and collective actions (Lebel et al., 2006). In adaptive governance, efforts could be made to harmonise traditional and modern governing structures (Getinet Assefa Gadena, 2009). In particular, the stakeholders should agree on mechanisms to enhance traditional leaders' interaction with the various arms of the government (legislative, executive and judiciary) (ECA, 2007). In Ethiopia, the strengthening of the interactions between existing formal and informal local governance systems analyzed by Spielman et al. (2009) may be a particularly promising strategy in development efforts.

\section{Conclusions}

Diverging views on methodologies are not necessarily a hindrance to technology system implementation in sustainable development efforts. Nevertheless, to overcome the difficulties experienced in dealing with complex technologies and impact studies, stakeholders should seek basic agreements on cooperation and objectives without insisting on generally agreed definitions. If stakeholders operate on the basis of different moral systems, cooperation could be improved by intensive dialogues and respecting pluralistic views. The use of a hierarchical system with ethical, ecological, economic, technological, legal and policy planes is helpful for this purpose. The evaluation of sustainable development from different perspectives or in different contexts further contributes to overcoming difficulties. 
In a facilitation process dealing with simple technology systems, adaptive management can easily integrate scientific contributions. In more complex systems, however, unprepared stakeholders are unable to efficiently apply mathematical, conceptual and graphical models to knowledge acquisition, decision support and negotiation. To make efficient use of these tools, an intensive dialogue between stakeholders is indispensable. Albeit of limited impact in the period under study, there are few alternatives to setting up on-site technology testing, demonstration and training facilities for selecting and implementing complex technology systems.

When evaluated in a narrow context, a simple technology system may readily produce positive results. When evaluated in broader contexts, however, the implementation may have consequences that threaten sustainable development if not complemented by the integration of additional technology systems, adequate natural resource management procedures and the revision of governance with respect to new rules and better integration of traditional governance structures.

The different evaluation contexts yield different but complementary results: in an agroecological context, the production may increase while the sustainability decreases; in the context of ecosystem service provision, technology implementation may result in higher production services, lower regulation services and more diverse cultural services; in the context of ecosocial sustainability, the measures undertaken to balance sustainable development on ecological, economic and social planes may prove to be insufficient for sustainable development. Hence, the evaluation within different contexts or from different perspectives is fruitful and recommended for sustainability assessments.

\section{Acknowledgments}

The Austrian Development Corporation (ADC), the Swiss Development Corporation (SDC) and BioVision Foundation, Zurich, Switzerland, provided financial support to the International Centre of Insect Physiology and Ecology (ICIPE). The assistance by Ethiopian Authorities and the collaboration of the Luke community is greatly appreciated.

\section{References}

Afeissa, H.-S. (2008). The transformative value of ecological pragmatism. An Introduction to the Work of Bryan G. Norton. S.A.P.I.E.N.S. Vol.1, 73-79. [http://sapiens.revues.org/88] [retrieved on July 14, 2011].

Anonymous (2011a). Extreme poverty. [http://en.wikipedia.org/wiki/Extreme_poverty] [retrieved on July 29, 2011].

Anonymous (2011b). Les trois piliers du développement durable : historique et bilan de la politique française.

[http://www.pdfmeta.com/be/les\%20pilier\%20du\%20developpement\%20durable -pdf-1.html] [retrieved on July 31, 2011].

Aseffa Abreha, Getachew Tikubet \& Baumgärtner, J. (Eds.) (2003). Resource Management for Poverty Reduction. Approaches \& Technologies. Ethiopian Social Rehabilitation and Development Fund, Addis Ababa, Ethiopia. 
Ayalneh Bogale, Hagedorn, K. \& Korf, B. (2002). Why does poverty persist in rural Ethiopia? Contributed paper selected for presentation at the 25th International Conference of Agricultural Economists, August 16-22, 2002, Durban, South Africa.

Barrett, J.C. (1989). Tsetse control, land use and livestock in the development of the Zambezi valley, Zimbabwe: some policy considerations. ILCA ALPAN Network Paper 19. International Livestock Research Institute. Repository on Livestock Research. [http:/ / mahider.ilri.org/handle/10568/4253] [retrieved on July 28, 2011].

Baumgärtner, J., Bieri, M., Buffoni, G., Gilioli, G., Gopalan, H., Greiling, J., Getachew Tikubet \& van Schayk, I. (2001). Human health improvement in Sub-Saharan Africa through integrated management of arthropod transmitted diseases and natural resources. Cadernos de Saúde Pública, Vol.17 (suppl), 37-46.

Baumgärtner, J., Getachew Tikubet, Melaku Girma, Sciarretta, A., Shifa Ballo \& Trematerra, P. (2003). Cases for adaptive ecological systems management. Redia Vol.LXXXVI, 165-172.

Baumgärtner, J., Gilioli, G. \& Huppenbauer, M. (2008a). Ethical issues in adaptive management of Sub-Saharan ecosocial systems. In: Ecological Management: New Research. Alonso, M.S. \& Rubio, I.M. (Eds.), pp. 77-102. Happauge: Nova Science Publishers.

Baumgärtner, J., Gilioli, G., Getachew Tikubet \& Gutierrez, A.P. (2008b). Eco-social analysis of an East African agro-pastoral system: management of tsetse and trypanosomiasis. Ecological Economics, Vol.65, 125-135.

Baumgärtner, J., Getachew Tikubet, Gilioli, G., Gutierrez, A.P., Sciarretta, A. \& Trematerra, P. (2008c). Implicazioni ecosociali nel miglioramento della salute del bestiame tramite la gestione di artropodi vettori di malattie in Etiopia. Atti Accademia Nazionale Italiana di Entomologia, Anno LV, 2007, 73-78.

Baumgärtner, J., Getachew Tikubet \& Gilioli, G. (2010). Towards adaptive governance of common-pool mountainous agropastoral systems. Sustainability, Vol.2, 1448-1471.

Belete Anteneh Tariku (2006). Studies on cattle milk and meat production in Fogera Woreda: production systems, constraints and opportunities for development. M. Sc. Thesis. Debub University, Awassa College of Agriculture, Awassa, Ethiopia.

Bellù, L.G. \& Liberati, P. (2005) Impacts of Policies on Poverty. Absolute poverty lines. Conceptual and technical material. Module 005. Food and Agriculture Organization of the United Nations (FAO), Rome.

Carpenter, H. (2009). Most dangerous innovation misperception - the silver bullet approach. [http://www.cloudave.com/1138/] [retrieved on May 24, 2011].

Chinsinga, B. (2003). The participatory development approach under a microscope: the case of the poverty alleviation program in Malawi. Journal of Social Development in Africa, Vol.18, 129-144.

Costanza, R. \& Daily, H.E. (1992). Natural capital and sustainable development. Conservation Biology, Vol.6, 3-46.

Daily, G. \& Dasgupta, S. (2007). Concept of ecosystem services. In: Encyclopedia of Biodiversity, Levin, S.A. (Ed.), pp. 353-362. New York: Academic Press.

Dransfield, R.D., Brightwell, R., Kyorku \& Williams, B. (1990). Control of tsetse fly (Diptera: Glossinidae) populations using traps at Nguruman, south-west Kenya. Bulletin of Entomological Research, Vol.80, 265-276. 
ECA (2007). Harnessing Traditional Governance in Southern Africa. Economic Commission for Africa. Southern Africa Office.Workshop on "Harnessing Traditional Governance in Southern Africa", October 18-19; Johannesburg, South Africa.

Eenhoorn, H. \& Becx, G. (2009). Constrain constraints! A study into real and perceived constraints and opportunities for the development of smallholder farmers in Sub-Sahara Africa. A public lecture, Wageningen, February 17th, 2009. [http://www.signschoolfeeding.org/_dynamic/downloads/Constraints \%20Constrained $\% 20$ final $\% 2$ 0A4\%20draft.pdf] [retrieved on May 20, 2011].

Ejigu Jonfa \& Waters-Bayer, A. (2005). Unlocking Farmers' Potential. Institutionalising Farmer Participatory Research and Extension in Southern Ethiopia. Project Experience Series, Farm-Africa, London.

ESDN (2010). European Sustainable Development Network. Indicators and Monitoring. Germany. [http:/ / www.sd-

network.eu/?k=country\%20profiles\&s=indicators\&country=Germany] [retrieved on July 30, 2011].

FAO (2011). The ecosystem approach to fisheries. Issues, terminology, principles, institutional foundations, implementation and outlook. Food and Agriculture Organization of the United Nations Fisheries Technical Paper. No. 443.

[ftp://ftp.fao.org/docrep/fao/006/y4773e/y4773e00.pdf] [retrieved on May 15, 2011).

Folke, C., Hahn. T., Olsson, P. \& Norberg, J. (2005). Adaptive governance of social-ecological systems. Annual Review of Environment and Resources, Vol.30, 441-473.

Gallagher, R. \& Appenzeller, T. (1999). Beyond reductionism. Science, Vol.284, No. 5411,79.

Getachew Tikubet, Shifa Ballo \& Amare Birhanu (2003). Community-based tsetse control: a model project within a sustainable agriculture framework. In: Resource Management for Poverty Reduction Approaches \& Technologies. Aseffa Abreha, Getachew Tikubet \& Baumgärtner, J. (Eds.), pp. 153-164. Ethiopian Social Rehabilitation and Development Fund, Addis Ababa, Ethiopia.

Getachew Tikubet, Lulseged Belayhun, Sciarretta A., Gilioli, G., Teame Hagos, Trematerra P., Gutierrez, A.P. \& Baumgärtner, J. (2006). Ecosocial effects of participatory tsetse (Glossina spp.) (Diptera Glossinidae) and bovine trypanosomiasis management at Luke, Southwestern Ethiopia. Bollettino di Zoolologia agraria e Bachicoltura, Serie II, Vol.38, No.3, 225-236.

Getinet Assefa Gadena (2009). Legal institutional hierarchies, justice and social order in Gurage area of Ethiopia. In: Proceedings of the 16th International Conference of Ethiopian Studies. Ege, S., Aspen, H., Birhanu Teferra \& Shiferaw Bekele (Eds.), Trondheim, Norway.

Gilioli, G. \& Baumgärtner, J. (2007). Adaptive ecosystem sustainability enhancement in SubSaharan Africa. EcoHealth, Vol.4, 428-444.

Gliessman, S.R. (2000). The ecological foundations of agroecosystem sustainability. Chapter 1 in Agroecosystem Sustainability : Developing Practical Strategies. Gliessman, S.R. Boca Raton: CRC Press.

Gliessman, S.R. (2007). Agroecology: the Ecology of Sustainable Food Systems. Boca Raton: CRC Press.

Goodland, R. (1995). The concept of environmental sustainability. Annual Review of Ecology and Systematics, Vol.26, 1-24. 
Gryseels, G., Abiye Astatke, Anderson, F.M. \& Getachew Assemenew (1984). The use of single oxen for crop cultivation in Ethiopia. ILCA Bulletin, Vol.18, 20-25.

Gutierrez, A.P., Gilioli, G. \& Baumgärtner, J. (2009). Eco-social consequences of disease management in East African agro-pastoral systems: policy implications. Proceedings of the National Academy of Sciences U.S.A, Vol.106: 13136-13141.

Haldermann, M. (2005). The political economy of pro-poor livestock policy-making in Ethiopia. PPLPI working paper 14. Pro-poor Livestock Policy Initiative (PPLPI), FOOD and Agriculture Organization of the United Nations, Rome.

Hardin, G. (1968). The tragedy of the commons. Science, Vol.162, 1243-1248.

Hassan, R.M., Scholes, R. \& Ash, N. (2005). Ecosystems and Human Well-being: Current State and Trends: Millenium Ecosystem Assessment. Findings of the Conditions and Trends Working Group. Washington: Island Press.

Hawando Tamirie (2006). Desertification in Ethiopian highlands. RALA report no. 200. [www.rala.is/rade/ralareport/Hawando.pdf] [retrieved on June 16, 2006].

Hein, L., Van Koppen, K., De Groot, R.S. \& van Ierland, E.C. (2006) Spatial scales, stakeholders and the valuation of ecosystem services. Ecological Economics, Vol.57, 209-228.

Heiniger, U. (2009). Tef (Eragostis tef [Zucc.] Trotter) - ein altes, unbekanntes Getreide wird Mode. Universität Zürich, Zürich, Switzerland.

[http://www.weiterbildung.uzh.ch/programme/ethnobot/unterlagen.html] [retrieved on July 22, 2011].

Herren, H.R., Baumgärtner, J. \& Gilioli, G. (2007). From integrated pest management to adaptive ecosystem management. In: Farming with Nature: the Science and Practice of Ecoagriculture, Scherr, S. \& McNeely, J. (Eds.), pp. 178-190. Washington D.C.: Island Press.

Holling, C. S. (Ed.) (1978). Adaptive Environmental Assessment and Management. New York: John Wiley.

Holling, C.S. (2001). Understanding the complexity of economic, ecological, and social systems. Ecosystems, Vol.4, 390-405.

Huppenbauer, M. \& De Bernardi, J. (2003). Kompetenz Ethik für Wirtschaft, Wissenschaft und Politik. Ein Tool für Argumentation und Entscheidungsfindung. Zürich: Versus Verlag.

Huppenbauer, M. \& Bleisch, B. (2011). Ethische Entscheidungsfindung. Ein Handbuch für die Praxis. Zürich: Versus Verlag.

ICRISAT (2009). Bio-economic Modeling in Natural Resource Management [http://www.icrisat.org/gt-mpi/ResearchBreifs/NRM.pdf] [retrieved on 14 September 2009].

ILRI (2011). Why livestock matter. International Livestock Research Institute (ILRI), Nairobi, Kenya.

[www.ilri.org] [retrieved on July 29, 2011].

Jiggins, J. \& Röling, N. (2000). Adaptive management: potential and limitations for ecological governance. International Journal of Agricultural Resources, Governance and Ecology, Vol.1, 28-42.

Jørgensen, S.E. (Ed.) (2009). Ecosystem Ecology. Amsterdam: Elsevier.

Jobarteh, D., Beix, V., Engelbrecht, S., Franke, B., Okyere, K., Omotola, T. \& Rodriguez, C. (2011). Africa Progress Report 2011. Africa Progress Panel, Geneva, Switzerland. 
Koshel, P. \& Mcallister, K. (Rapporteurs, National research Council). (2008). Transitioning to Sustainability Through Research and Development on Ecosystem Services and Biofuels: Workshop Summary. Washington: National Academic Press.

Leak, S.G.A., Woudyalew Mulatu, Rowlands, G. J. \& d'Ieteren G.D.M. (1995). Trial of a cypermethrin 'pour-on' insecticide to control Glossina pallidipes, G. fuscipes fuscipes and G. morsitans submorsitans (Diptera: Glossinidae) in south-west Ethiopia. Bulletin of Entomological Research, Vol.85, 241-251.

Lebel, L., Anderies, J.M., Campbell, B., Folke, C., Hatfield-Dodds, S., Hughes, T.P. \& Wilson, J. (2006). Governance and the capacity to manage resilience in regional socialecological systems. Ecology and Society, Vol.11, art. 19.

[http:// www.ecologyandsociety.org/vol11/iss1/art19] [retrived on July 29, 2011].

Leong, L.M. (2010). Thinking through Complexity, Managing for Uncertainty. Ethos Issue 7 [http://www.cscollege.gov.sg/cgl/pub_ethos_10c1.htm] [retrieved on May 15, 2011].

Meyerson, L.A., Baron, J., Melillo, J.M., Naiman, R.J., O'Malley, R.I., Orians, G., Palmer, M.A., Pfaff, A.S.P., Running, S.W. \& Sala, O.E. (2005). Aggregate measures of ecosystem services: can we take the pulse of nature ? Frontiers in Ecology and the Environment, Vol.3: 56-59.

Mitiku Haile, Fetien Abay \& Waters-Bayer, A. (2001). Joining forces to discover and celebrate local innovation in land husbandry in Tigray, Ethiopia. In: Farmer Innovation in Africa: A Source of Inspiration for Agriculture. Reij, Ch., Waters-Bayer, A. (Eds). Earthscan: London, UK.

Montagna, M., Lozzia, G.C., Andreis, C., Giorgi, A. \& Baumgärtner J. (2011). The Beetle (Coleoptera) and True bug (Heteroptera) species pool of the alpine "Pian di Gembro" wetland (Villa di Tirano, Italy) and its conservation. Journal of Entomological and Acarological Research, Vol.43, 7-22.

Nell, A.J. (2006). Quick scan of the livestock and meat sector in Ethiopia. Issues and opportunities. Wageningen International, Wageningen.

Newton, L.H. (2003). Ethics and Sustainability. Sustainable Development and the Moral Life. Upper Saddle River: Prentice Hall.

OAU (2001). Pan African Tsetse and Trypanosomosis Eradication Campaign (PATTEC). Enhancing Africa's prosperity. Plan of Action. Organization of African Unity, Addis Ababa.

[www.africa-union.org/Structure_of_the_Commission/Pattec/

PATTECAction_Plan_English.pdf] [retrieved on June 2, 2011].

OECD (2011). Human development. Source publication: Glossary of Environment Statistics. Studies in Methods, Series F, No. 67, United Nations, New York, 1997. [http:/ / stats.oecd.org/glossary/detail.asp?ID=2626] [retrieved on May 15, 2011].

Omamo, S.W. \& d'Ieteren, G.D.M. (2003). Managing animal trypanosomosiasis in Africa: issues and options. Revue scientifique et technique de l'Office international des épizooties, Vol.22, No.3, 989-1002.

Ostrom, E., Burger, J., Field, C.B., Norgaard, R.B. \& Policansky. D. (1999). Revisiting the commons: Local lessons, global challenges. Science, Vol.284, 278-282.

Owen, S. (2003). Is there a meaningful definition of sustainability? Plant Genetic Resources, Vol.1, 5-9. 
Pawłowski, A. (2008). How many dimensions does sustainable development have ? Sustainable Development, Vol.16, 81-90.

Pawłowski, A. (2011). Sustainable Development as a Civilizational Revolution. A Multidisciplinary Approach to the Challenges of the 21st Century. London: Taylor \& Francis.

Peterson, G., Pope, S., De Leo, G.A., Janssen, M.A., Malcolm, J.R., Parody, J.M., Hood, G. \& North, M. (1997). Ecology, ethics, and advocacy. Ecology and Society, Vol.1, 17. [http://www.consecol.org/vol1/iss1/art17/] [retrieved on March 25, 2008].

Regev, U., Gutierrez, A.P., Schreiber S.J. \& Zilberman, D. (1998). Biological and economic foundations of renewable resource exploitation. Ecological Economics, Vol.26, 227242.

Reinhardt, E. (2006). Working Together: UN Agencies Battle Tsetse...and Rural Poverty. United Nations Chronicle. [www.un.org/chronicle] [retrieved on June 10, 2006].

Rogers, D.J. \& Randolph, S.E. (1988). Tsetse flies in Africa: bane or boon. Conservation Biology, Vol.1, 57-65.

Röling, N.G. (1995). What to think of extension?: a comparison of three models of extension practice. In Article for the Francophone Issue of AERDD Bulletin; Salamna N., Ed.; International Centre for Development Oriented Research in Agriculture (ICRA): Montpellier, France.

Resilience Alliance (2010). [http://www.resalliance.org/index.php?id=560] [retrieved on February, 2, 2010].

Saini, R.K., Ng'eny-Mengetch, A. \& Ogendo, I. (1999). Fighting Africa's Deadly Fly - New Ecofriendly Solutions for Tsetse Management. Accomplishments of the European Union funded Project on Interactive Development and Application of Sustainable Tsetse Management Technologies for Agropastoral Communities in Africa. International Centre of Insect Physiology and Ecology (ICIPE), Nairobi, Kenya.

Samuel Gebreselassie (2006). Intensification of Smallholder Agriculture in Ethiopia: Options and Scenarios. Draft paper prepared for the Future Agricultures Consortium Meeting at the Institute of Development Studies 20-22 March 2006. [http://www.futureagricultures.org/pdf\%20files/SG_paper_3.pdf] [retrieved on May 15, 2011].

Sayer, J. A. \& Campbell, B.M., (2004). The Science of Sustainable Development. Local Livelihoods and the Global Environment. Cambridge: Cambridge University Press.

Sciarretta, A., Baumgärtner, J., Getachew Tikubet, Melaku Girma \& Trematerra, P. (2005a). Design of a trapping system for monitoring the spatio-temporal occurrence of tsetse (Glossina spp.). Rivista Italiana di Agrometeorologia, Vol.3, 24-29.

Sciarretta, A., Melaku Girma, Getachew Tikubet, Lulseged Belayehun, Shifa Ballo \& Baumgärtner, J. (2005b). Development of an adaptive tsetse population management scheme for the Luke community, Ethiopia. Journal of Medical Entomology, Vol.42, 1006-1019.

Sciarretta, A., Getachew Tikubet, Baumgärtner, J., Melaku Girma \& Trematerra, P. (2010). Spatial clustering and associations of two savannah tsetse species, Glossina morsitans submorsitans and Glossina pallidipes (Diptera, Glossinidae), for guiding interventions in an adaptive management framework. Bulletin of Entomological Research, Vol. 100, 661-670.

Schmidt, J. (Ed.) (1997). Rural infrastructure as a cause and consequence of rural economic development and quality of life. Proceedings of a Regional Workshop Birmingham, 
Alabama, February 1997. Southern Extension/Research Activities-Information Exchange Group-16 (SERA-IEG-16). Southern Rural Development Center SRIEG-16 Publication No. 5 SRDC Publication No. 207, July 1997.

[http://srdc.msstate.edu/publications/archive/207.pdf] [retrieved on July 12, 2011].

Shibru Tedla \& Kifle Lemma (1998). Environmental Management in Ethiopia: Have the National Conservation Plans Worked? Environmental Forum Publication Series 95, No.1, Organization for Social Science Research in Eastern and Southern Africa (OSSREA), Addis Ababa, Ethiopia.

Sisay Asefa \& Tesfaye Zegeye (2003). Rural Poverty, Food Insecurity and Environmental Degradation in Ethiopia: A Case Study from South Central Ethiopia. 2nd EAF/IDR International Symposium on Contemporary Development Issues in Ethiopia, July 11-13, Addis Ababa, Ethiopia.

[http://homepages.wmich.edu/ asefa/Conference \%20and \%20Seminar/Papers/2 003\%20papers/Asefa,\%20Sisay_\%20Zegeye,\%20Tesfaye.pdf] [retrieved on May 24, 2011].

Smith, L.S. \& Smith, T.M. (2000). Ecology and Field Biology. San Francisco: Addison Wesley.

Spickler, A.R., Roth, J.A., Galyon, J., Lofstedt, J. (2010). Emerging and Exotic Diseases of Animals. Ames: the Centre for Food Security and Public Health, Iowa State University.

Spielman, D.J., Cohen, M.J. \& Mogues, T. (2009). Local governance systems and smallholder cooperatives in Ethiopia. International Journal of Agricultural Resources, Governance and Ecology, Vol.8, 388-408.

Tesfaye Mengistidie Dore (2007).Characterization of cattle milk and meat production, processing and marketing system in Metema district, Ethiopia. M. Sc. Thesis, Hawassa University, Awassa College of Agriculture, Awassa, Ethiopia.

Torr, S., Eisler, M., Coleman, P., Morton, J. \& Machila, N. (2002). Integrated control of ticks and tsetse: A report for the DFID Advisory and Support Services Commission (Project ZV0151; NRI code V0160).

[http://www.nri.org/tsetse/FAQ/Pdf/torr02.pdf] [retrieved on June 3, 2011].

TradingEconomics (2011). Ethiopia World Bank Data.

[http://www.tradingeconomics.com/ethiopia/arable-land-hectares-wb-data.htm] [retrieved on July 12, 2011).

Tripp, R. (2006). Is low external input technology contributing to sustainable agricultural development? Natural Resource Perspectives, Vol.102.

UN (2005). Millenium Development Goals. United Nations (UN).

[www.un.org/milleniumgoals/bkgd.shtml] [retrieved on May 20, 2011].

UNSTATS (2006). United Nations Statistics Division.

[htp://unstats.un.org/unsd/default.htm] [retrieved on June 18, 2007].

UNSTATS (2008). Millenium Development Goals Indicators.

[http://mdgs.un.org/unsd/mdg/Host.aspx?Content=Indicators/OfficialList.htm] [retrieved on September 14, 2011].

Waage, J. (2010). Technology: it is not a silver bullet in international development. [http://www.publicservice.co.uk/] [retrieved May 19, 2011]. 
Waltner-Toews, D., Kay, J.K., Neudoerffer, C. \& Gitau, T. (2003). Perspective changes everything: managing ecosystems from inside out. Frontiers in Ecology and the Environment, Vol.1, 23-30.

WCED (1987). Our Common Future. United Nations World Commission on Environment and Development. Oxford: University Press.

World Bank (1986). Poverty and Hunger: Issues and Options for Food Security in Developing Countries. A World Bank Policy Study, Washington D.C.

Yigzaw Dessalegn \& Yohannese Mehari (2007). Farmers attempt to solve shortage of draught power at Bure PLW. Improving productivity and market Success of Ethiopian Farmers (IPMS). Newsletter 2(2).

[http://www.ipms-ethiopia.org/enewsletter/dispNews.asp?newsId=277] [retrieved on July 30, 2011]. 


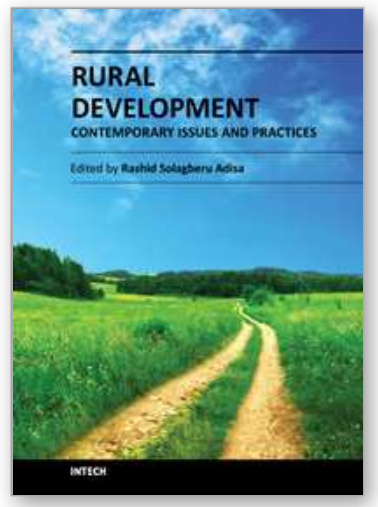

\author{
Rural Development - Contemporary Issues and Practices \\ Edited by Dr. Rashid Solagberu Adisa
}

ISBN 978-953-51-0461-2

Hard cover, 408 pages

Publisher InTech

Published online 20, April, 2012

Published in print edition April, 2012

Development of rural areas has witnessed increasing attention globally, especially over the past three to four decades. The highpoint in the renewed global interest in the development of rural people and their environment was reached with the setting of the Millennium Development Goals (MDGs) in the year 2000. All of the set goals are basically rural development goals. With less than four years to the deadline for the achievement of the MDGs, it is almost certain that the goals are far from being achieved in, especially, most developing countries for whom the MDGs were essentially set. The struggle thus continues for rural development. As long as problems of poverty, disease, illiteracy, unemployment, poor infrastructure, environmental degradation and others persist (or increase) in rural communities, better and more resultoriented solutions to perennial and emerging problems of rural communities would be required. But rural development, in spite of the variations in thresholds of rurality among nations, is not exclusively a Third World or \&lsquo;developing countries\&rsquo; process, owing to its multi-dimensionality. It is a global phenomenon that obviously requires global strategies. This book not only looks at rural development from its multidimensional perspectives, it is also a product of the experiences and expertise of distinguished scholars across the continents. Aiming to provide a comprehensive single volume that addresses salient issues and practices in rural development, the book covers themes ranging from sustainable agriculture, biodiversity conservation, strategic environmental assessment, renewable energy, rural financial resources, assessment of protected areas to statistics for rural development policy. Other subject matters covered by the book include social marginality, land use conflict, gender, cooperatives, animal health, rural marketing, information and communication technology, micro-business, and rural economic crisis. The book is thus an invaluable source of useful information on contemporary issues in rural development for researchers, policy makers, and students of rural development and other related fields.

\title{
How to reference
}

In order to correctly reference this scholarly work, feel free to copy and paste the following:

Johann Baumgartner and Getachew Tikubet (2012). From Tsetse Control to Sustainable Rural Development Progress and Opportunities for an Ethiopian Community, Rural Development - Contemporary Issues and Practices, Dr. Rashid Solagberu Adisa (Ed.), ISBN: 978-953-51-0461-2, InTech, Available from: http://www.intechopen.com/books/rural-development-contemporary-issues-and-practices/from-tsetse-controlto-sustainable-rural-development-progress-and-opportunities-in-an-ethiopian-comm

\section{INTECH}

open science | open minds 


\section{InTech Europe}

University Campus STeP Ri

Slavka Krautzeka 83/A

51000 Rijeka, Croatia

Phone: +385 (51) 770447

Fax: +385 (51) 686166

www.intechopen.com

\section{InTech China}

Unit 405, Office Block, Hotel Equatorial Shanghai No.65, Yan An Road (West), Shanghai, 200040, China

中国上海市延安西路65号上海国际贵都大饭店办公楼 405 单元 Phone: +86-21-62489820

Fax: +86-21-62489821 
(C) 2012 The Author(s). Licensee IntechOpen. This is an open access article distributed under the terms of the Creative Commons Attribution 3.0 License, which permits unrestricted use, distribution, and reproduction in any medium, provided the original work is properly cited. 